\author{
V.R. Kushcherbaeva ${ }^{1}$, A.A. Bakibaev ${ }^{1}$, D.A. Kurgachev', \\ M.A. Fomchenkov ${ }^{1}$, A.G. Zhaksybaeva ${ }^{3}$, V.S. Malkov ${ }^{1}$ \\ ${ }^{I}$ Tomsk State University, Russia; \\ ${ }^{2}$ Tomsk Polytechnic University, Russia; \\ ${ }^{3}$ L.N. Gumilyov Eurasian National University, Astana, Kazakhstan \\ (E-mail: kuscherbaeva_venera@mail.ru)
}

\title{
Study of hydrolytic stability of glycolurils under alkaline conditions
}

\begin{abstract}
This article is devoted to the hydrolytic stability of glycoluryls, which are a promising class of organic compounds characterized by a wide spectrum of psychopharmacological activity. Hydrolysis of glycoluril and a mixture of N,N-dimethylglycoluryls was carried in alkaline conditions in water at reflux. The hydrolysis of a mixture of N,N-dimethylglycoluril was carried out for 5 days before the complete decomposition of the mixture of isomers. Quantitative and qualitative analysis of the hydrolyzates was carried out by high-performance liquid chromatography, thin layer chromatography, and gas chromatography / mass spectrometry. The mixture of N,N-dimethylglycoluril practically did not undergo hydrolysis during the first three days. The rate of hydrolysis of cis and trans isomers of N,N-dimethylglycoluril is the same. It means that the destruction of heterocycles occurs through the stages of successive hydrolytic cleavage of the $\mathrm{C}-\mathrm{N}$ bond in the initial glycolyls and hydantoins: the glycolurils form anions which rearrange themselves into hydantoins by eliminating the corresponding ureas in alkaline conditions. The final products of hydrolysis of glycoluril and a mixture of the cis- and trans- isomers of N,N-dimethylglycoluril are hydantoic acids. The hydrolysis of glycoluril, as well as mixtures of the cis and trans isomers of N,N-dimethylglycoluril considered in the article can be used to evaluate hydrolytic stability, which in turn will give some information on the mechanisms of their action in the body.
\end{abstract}

Keywords: glycoluril, N-alkylglycoluril derivatives, hydantoin, glyoxal, biologically active compounds, hydrolysis, hydantoic acid, heterocycle.

\section{Introduction}

Glycolurils attract attention by their polyfunctionality, due to which a lot of practically valuable substances were obtained on the basis of them, namely, bleach activators [1], explosives [2, 3], additives to various polymers [4], supramolecular compounds [5, 6] and others [7]. In recent decades, an intensive search for new biologically active compounds has been carried out among the glycoluril derivatives $[8,9]$, and some of them have already been used as medications of neurotropic action, namely, mebicar and albicar.

Investigation of the hydrolytic stability of biologically active compounds gives certain information about the mechanisms of their action in the body. It is known that glycolurils are sufficiently stable with respect to acid hydrolysis, as it is clearly illustrated by the example of mebicar (tetramethylglycoluril), which decomposes on boiling in $25 \%$ sulfuric acid for more than 50 hours [10]. At the same time, the hydrolytic properties of glycolurils under alkaline conditions are much less studied. The aim of this research is to study ability of glycolurils 1, 2, 3 to hydrolytic decomposition under alkaline conditions to understand the hydrolytic stability of glycolurils in more detail.

\section{Experimental}

Synthesis of 2,4- and 2,6-dimethylglycoluril (2,4-DMGU and 2,6-DMGU) (2, 3)

Mixture of isomers 2, 3 was synthesized by reaction of glyoxal with methylurea [3]. There were obtained white crystals with $\mathrm{mp} 250{ }^{\circ} \mathrm{C}$. Yield was 26-42\%. 2: NMR ${ }^{1} \mathrm{H}\left(\mathrm{DMSO}-\mathrm{d}_{6}\right), \delta \mathrm{ppm}$ : $7.57(\mathrm{~s}, 2 \mathrm{H})$, $5.10(\mathrm{~s}, 2 \mathrm{H}), 2.60(\mathrm{~s}, 6 \mathrm{H}) . \mathrm{NMR}{ }^{13} \mathrm{C}\left(\mathrm{DMSO}_{-} \mathrm{d}_{6}\right), \delta \mathrm{ppm}: 27.42\left(-\mathrm{CH}_{3}\right), 67.39(-\mathrm{CH}<), 159.66(>\mathrm{C}=\mathrm{O})$. 3: NMR ${ }^{1} \mathrm{H}\left(\right.$ DMSO-d $\left._{6}\right), \delta$ ppm: $7.397 \mathrm{~s}(2 \mathrm{H}, \mathrm{NH}), 5.18 \mathrm{~d}(1 \mathrm{H}, \mathrm{CH}), 5.15 \mathrm{~d}(1 \mathrm{H}, \mathrm{CH}), 2.78 \mathrm{~s}\left(6 \mathrm{H}, \mathrm{CH}_{3}\right)$. ${ }^{13} \mathrm{C}$ NMR (DMSO-d $)$, $\delta$ ppm: $27.43\left(-\mathrm{CH}_{3}\right), 67.39(-\mathrm{CH}<), 75.63(-\mathrm{CH}<), 160.19(>\mathrm{C}=\mathrm{O})$.

Synthesis of glycoluril

Glycoluril was synthesized by condensation of urea with glyoxal [7]. Melting point is about $300{ }^{\circ} \mathrm{C}$. NMR ${ }^{1} \mathrm{H}\left(\mathrm{DMSO}_{-} \mathrm{d}_{6}\right), \delta$ ppm: $7.16(\mathrm{~s}, 2 \mathrm{H})$, 5.24. $(\mathrm{s}, 2 \mathrm{H}) . \mathrm{NMR}{ }^{13} \mathrm{C}\left(\mathrm{DMSO}^{-} \mathrm{d}_{6}\right), \delta$ ppm: $64.6(-\mathrm{CH}<), 160.30$ $(>\mathrm{C}=\mathrm{O})$.

\section{Hydrolysis of regioisomers of DMGU in alkaline medium}

Hydrolysis was carried out in a one-necked flask. There was added $1 \mathrm{~g}$ of mixture of 2, 3 with $10 \mathrm{~mL}$ of water. After $2.5 \mathrm{~g}$ of sodium hydroxide was charged. The solution was heated up to $100^{\circ} \mathrm{C}$. 
Analytical HPLC

Solutions were analyzed by HPLC on LUNA 5 u PFP (2) $(150 \times 4.6 \mathrm{~mm}, 5 \mu \mathrm{m}$ particle size $)$. The mobile phase consisted of water with acetonitrile in gradient mode. Summary time was 12 min. Temperature of column was $40{ }^{\circ} \mathrm{C}$; flow rate was $0.5 \mathrm{~mL} / \mathrm{min}$, the detection wavelength of UV detector was $195 \mathrm{~nm}$. Samples were dissolved in water at the ratio 1:1000.

\section{Results and Discussion}

The qualitative and quantitative composition of hydrolysates of glycoluril 1 and DMGU 2, 3 was studied using TLC and HPLC control and using GC-MS data. In the course of our studies, we showed that the hydrolysis of glycoluril 1 and its dimethyl derivatives 2, 3 in aqueous solutions of sodium hydroxide is accompanied by the formation of the corresponding hydantoins 4, 5 and the corresponding hydantoic acids of 6, 7:

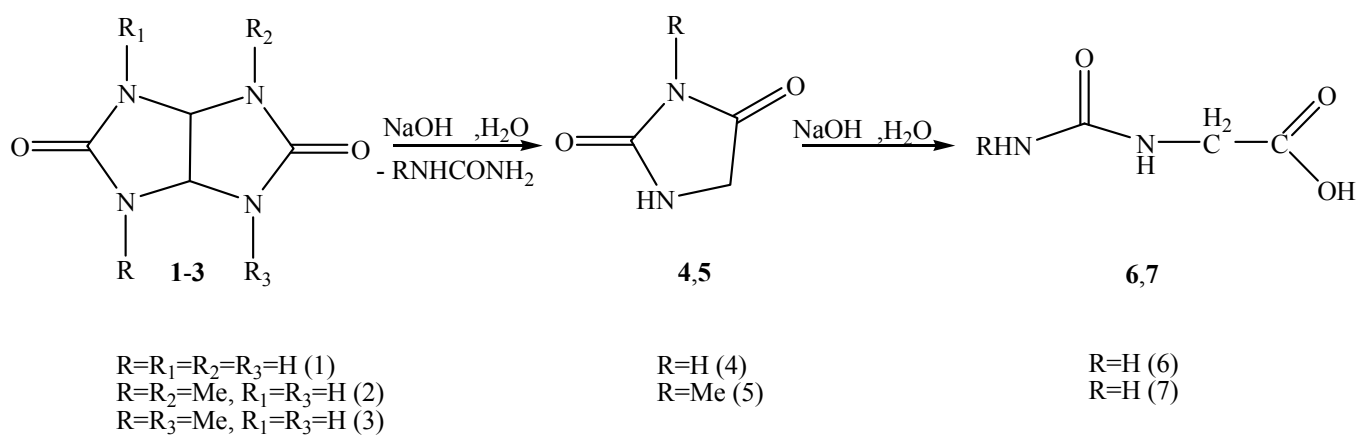

We have established that the hydrolysis of glycoluril 1 to hydantoin at $100^{\circ} \mathrm{C}$ was quick $(10 \mathrm{~min}$.). Hydrolysis of hydantoin 4 under alkaline conditions leads to formation of hydantoic acid 6. Similarly, dimethyl derivatives of glycoluril 2, 3 were used. We studied alkaline hydrolysis of the mixture of the regioisomers 2 , 3 in conditions of the HPLC control.

The hydrolysis of the regioisomers 2 and 3 was carried out in alkaline conditions for 5 days. Concentrations of DMGU 2, 3 remained practically unchanged upon boiling during the first two days (Fig. 1). Unknown peaks 8, 9, 10 were revealed on the chromatograms (Fig. 1-3), indicating destruction of the regioisomers 1, 3 in 5 days. The rates of hydrolysis of 2 and 3 were equal, because we saw the same trends in concentration of DMGU over time.

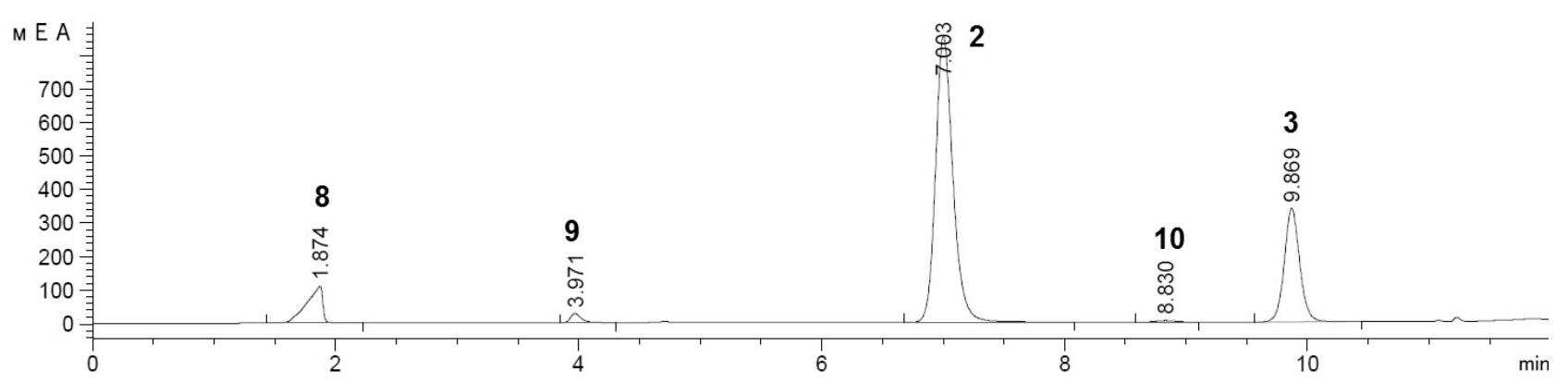

Figure1. HPLC of DMGU hydrolysis in 1 day

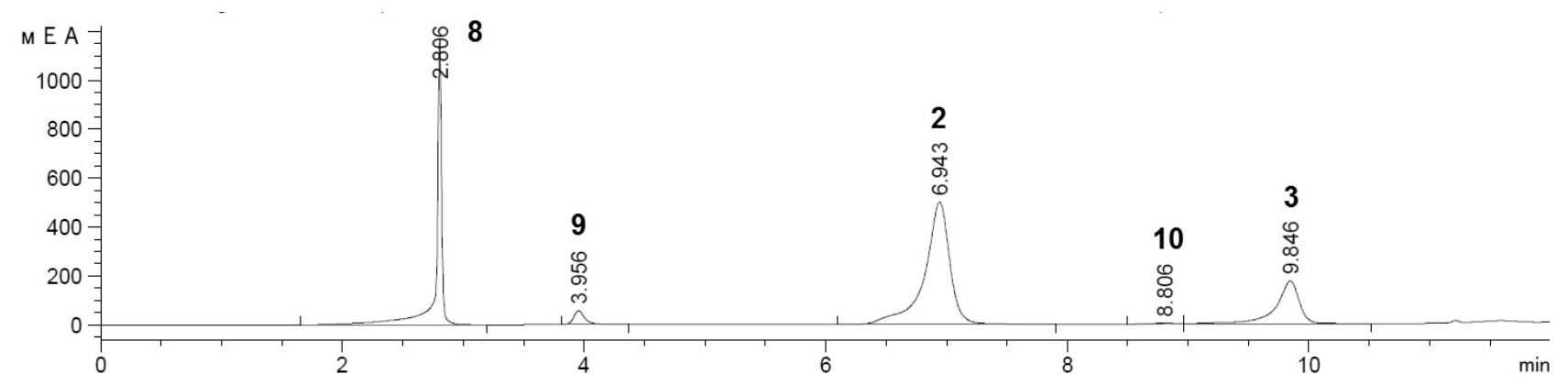

Figure 2. HPLC of DMGU hydrolysis in 3 days 


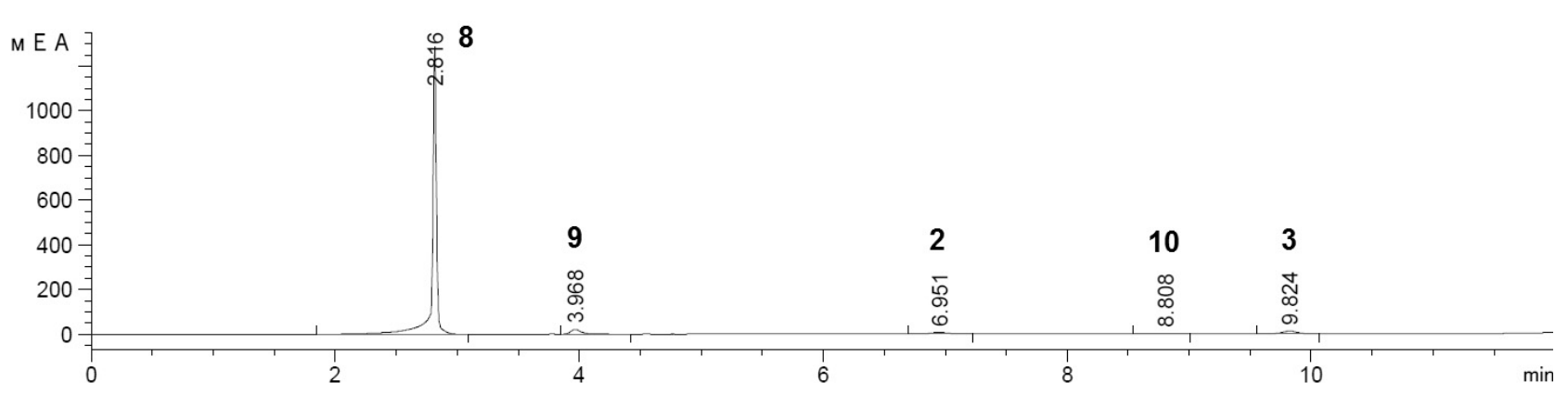

Figure 3. HPLC of DMGU hydrolysis in 5 days

A simplified scheme of hydrolysis of glycolurils 1-3 to hydantoins 4, 5 and hydantoic acids 6,7 under alkaline conditions based on chromatogram data can be represented as follows:

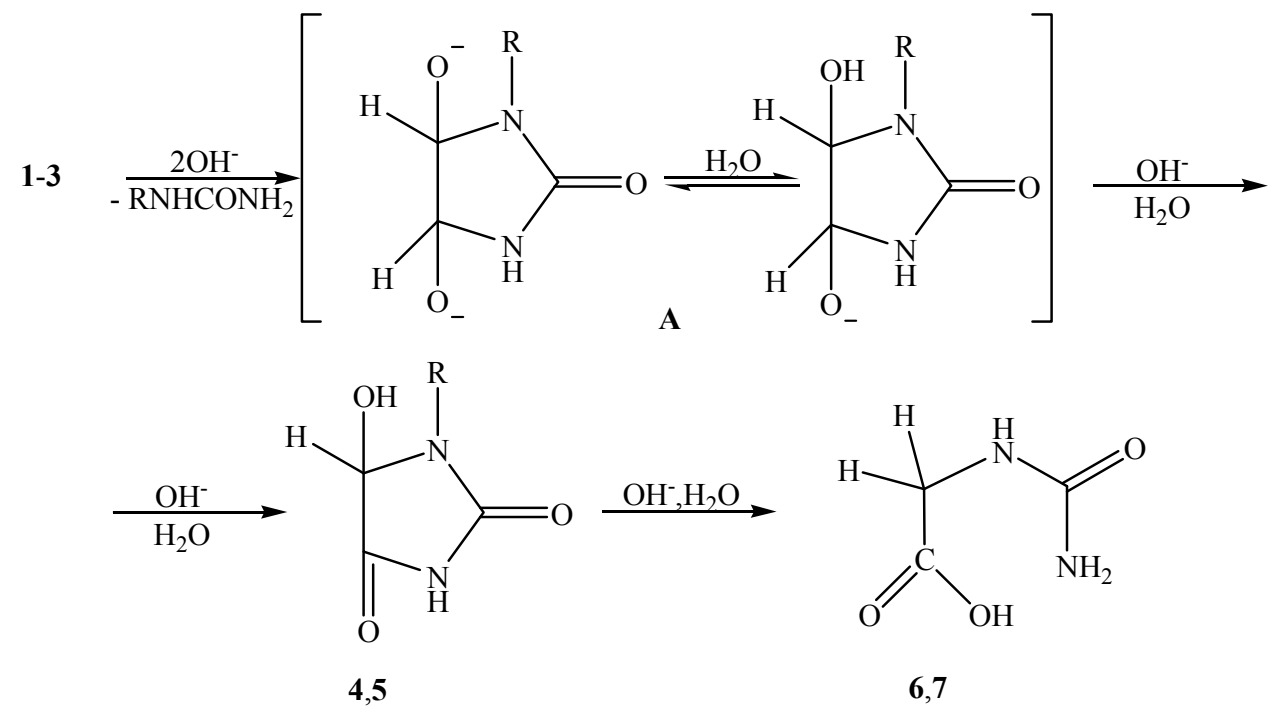

Glycolurils 1-3 form anion A under alkaline conditions in the initial phase through the elimination of the corresponding ureas, which are rearranged to hydantoins 4,5 , and that are easily hydrolyzed to hydantoic acids 6,7 .

\section{Conclusions}

Such studies as had been carried out showed that glycoluril 1 and DMGU 2, 3 are expected to undergo hydrolysis under alkaline conditions than in acid. Destruction of the heterocycles 1-3 occurs through the stages of consequential hydrolytic cleavage of the C-N bond in the initial glycolurils 1-3 and hydantoins 4, 5. Final products of glycolurils hydrolysis are hydantoic acids 6,7 .

\section{References}

1 Завельская В.Д. Основные достижения в области синтеза перспективных отбеливателей / В.Д. Завельская, 3.С. Замчук // Хим. промышленность: обзор, информ. - М.: НИИТЭХИМ, 1988. — 46 с.

2 Cui K. Synthesis and characterization of a thermally and hydrolytically stable energetic material based on N-nitrourea / K. Cui // Propellants Explos. Pyrotech. - 2014. — Vol. 38. - P. 662-669.

3 Zharkov M. Nitration of glycoluryl derivatives in liquid carbon dioxide / M. Zharkov // Mendeleev Commun. — 2015. Vol. 25. - P. 15, 16.

4 Кравченко А.Н. Химия уреидокарбоновых и уреилендикарбоновых кислот / А.Н. Кравченко, И.У. Чикунов // Успехи химии. - 2006. - № 3. - С. 217-233.

5 Lagona J. The cucurbit[n]uril family / J. Lagona // Angew. Chem. Int. Ed. — 2005. — Vol. 44. — P. 4844-4870.

6 Elemans J. Hierarchical self-assembly of amphiphilic metallohosts to give discrete nanostructures / J. Elemans, A. Rowan, R. Nolte // Ind. Eng. Chem. Res. — 2000. - Vol. 39. - P. 3419, 3420. 
7 Кравченко А.Н. Синтез гликольурилов и их аналогов / А.Н. Кравченко, В.В. Баранов, Г.А. Газиева // Успехи химии. - 2018. - Т. 87, Вып. 1. - С. 107, 108.

8 Kravchenko A. Synthesis of 2,4,6-trialkyl-8-(2,3-epoxypropyl)glycolurils / A. Kravchenko, V.V. Baranov, G.A. Gazieva // Mendeleev Communications. - 2013. - Vol. 23. - P. 104, 105.

9 Машковский М.Д. Лекарственные средства: справ. / М.Д. Машковский. — М.: Новая волна, 2005. — 1164 с.

10 Прокопов А.А. Экспериментальная фармакокинетика альбикара / А.А. Прокопов, Н.В. Костебелов, А.А. Берлянд // Хим.-фарм. журн. - 2002. - № 3. - С. 13-16.

\author{
В.Р. Кущербаева, А.А. Бакибаев, Д.А. Кургачев, \\ М.А. Фомченков, А.Ғ. Жақсыбаева, В.С. Мальков
}

\title{
Гликолурилдердің сілтілі жағдайлардағы гидролитикалық тұрақтылығын зерттеу
}

\begin{abstract}
Мақала психофармакологиялық белсенділікті сипаттайтын органикалық қосылыстардың болашағы сыныбы гликолурилдердің гидролитикалық тұрақтылығына арналған. Гликолурил мен N,N-диметилгликолурилдің гидролизін сілтілі суда қайнату жағдайында өткізді. N,N-диметилгликолурилдің қоспасының гидролизін 5 күн бойы изомерлердің қоспасы толық ыдырағанша жалғастырды. Гидролизаттардың сандық және сапалы талдауын жоғары тиімді сұйықтық хроматографиясының, жұқа қабатты хроматографияның және газды-хроматография/масс-спектрометрияның көмегімен өткізді. N,N-диметилгликолурил қоспасы алғашқы үш күн дегидролизге мүлде ұшырамады. N,N-диметилгликолурил изомерлерінің иис- пен транс-қоспалары гидролизінің жылдамдықтары бірдей. Нәтижесінде, гетероциклдердің бұзылуы C-N қосылыстарының тізбекті гидролитикалық ыдырауы сатысы арқылы бастапқы гликолурилдер мен гидантоиндерде жүреді: гликолурилдер аниондарды түзеді, олар сілтілі жағдайларда тиісті мочевиналардың ластауы жолымен гидантоиндерге топталады. Гликолурил мен $\mathrm{N}, \mathrm{N}$-диметилгликолурил изомерлерінің цис- пен транс-қоспасынан алынатын өнім гидантоинді қышқыл болып табылады. Мақалада қаралған гликолурилдің гидролизі, сонымен қатар $\mathrm{N}, \mathrm{N}$-диметилгликолурил изомерлерінің иис- және транс-қоспаларының гидролитикалық тұрақтылығын бағалау үшін қолданылуы мүмкін, ол, өз кезегінде, олардың ағзада әсер ету механизмдері туралы белгілі бір ақпаратты бере алады.
\end{abstract}

Кілт сөздер: гликолурил, $\mathrm{N}$-алкилгликолурилдің туындылары, гидантоин, гидантоин қышқылы, гетероцикл, глиоксаль, мочевина, биологиялық белсенді қосылыстар, гидролиз.

\section{В.Р. Кущербаева, А.А. Бакибаев, Д.А. Кургачев, М.А. Фомченков, А.Г. Жаксыбаева, В.С. Мальков \\ Исследование гидролитической устойчивости гликолурилов в щелочных условиях}

\begin{abstract}
Статья посвящена гидролитической устойчивости гликолурилов, которые являются перспективным классом органических соединений, характеризующихся широким спектром психофармакологической активности. Гидролиз гликолурила и смеси N,N-диметилгликолурилов проводили в щелочных условиях в воде при кипячении. Гидролиз смеси N,N-диметилгликолурилов был проведен в течение 5 дней до полного разложения смеси изомеров. Количественный и качественный анализ гидролизатов проводили с помощью высокоэффективной жидкостной хроматографии, тонкослойной хроматографии и газовой хроматографии/масс-спектрометрии. Смесь N,N-диметилгликолурила практически не подвергалась гидролизу в течение первых трех дней. Скорость гидролиза ицс- и транс-изомеров N,Nдиметилгликолурила одинакова. Сделан вывод о том, что разрушение гетероциклов происходит через стадии последовательного гидролитического расщепления связи C-N в исходных гликолурилах и гидантоинах: гликолурилы образуют анионы, которые в щелочных условиях путем элиминирования соответствующих мочевин перегруппировываются в гидантоины. Конечными продуктами гидролиза гликолурила и смеси изис- и транс-изомеров $\mathrm{N}, \mathrm{N}$-диметилгликолурила являются гидантоиновые кислоты. Рассмотренный в статье гидролиз гликолурила, а также смеси иис- и транс-изомеров $\mathrm{N}, \mathrm{N}$-диметилгликолурила могут быть использованы для оценки гидролитической устойчивости, которая, в свою очередь, будет давать определенную информацию о механизмах их действия в организме.
\end{abstract}

Ключевые слова: гликолурил, производные $\mathrm{N}$-алкилгликолурила, гидантоин, гидантоиновая кислота, гетероцикл, глиоксаль, мочевина, биологически активные соединения, гидролиз. 


\section{References}

1 Zavelskaya, V.D., \& Zumchuk, Z.S. (1988). Osnovnye dostizheniia v oblasti sinteza perspektivnykh otbelivatelei [Main achievements in the field of synthesis of promising bleaching agents]. Moscow: NIITEKHIM [in Russian].

2 Cui, K. (2014). Synthesis and characterization of a thermally and hydrolytically stable energetic material based on N-nitrourea. Propellants Explos. Pyrotech, 38, 662-669.

3 Zharkov, M. (2015). Nitration of glycoluryl derivatives in liquid carbon dioxide. Mendeleev Communications, 25, 15-16.

4 Kravchenko, A.N., \& Chikunov, I.U. (2006). Khimiia ureidokarbonovykh i ureilendikarbonovykh kislot [Chemistry of ureidocarboxylic and ureylenedicarboxylic acids]. Uspekhi khimii-Chemistry Advances, 3, 217-233 [in Russian].

5 Lagona, J. (2005). The cucurbit[n]uril family. Angew. Chem. Int. Ed, 44, 4844-4870.

6 Elemans, J., Rowan, A., \& Nolte, R. (2000). Hierarchical Self-Assembly of Amphiphilic Metallohosts To Give Discrete Nanostructures. Ind. Eng. Chem. Res., 39, 3419-3420.

7 Kravchenko, A.N., Baranov, V.V., \& Gazieva, G.A. (2018). Sintez hlikolurilov i ikh analohov [Synthesis of glycolurils and their derivatives]. Uspekhi khimii - Advances in Chemistry, 87(1), 107-108 [in Russian].

8 Kravchenko, A.N., Baranov, V.V., \& Gazieva, G.A. (2013). Synthesis of 2,4,6-trialkyl-8-(2,3-epoxypropyl)glycolurils. Mendeleev Communications, 23, 104-105.

9 Mashkovskii, M.D. (2005). Lekarstvennye sredstva [Medicines]. Moscow: Novaia volna [in Russian].

10 Prokopov, A.A., Kostebelov, A.A., \& Berland, N.V. (2002). Eksperimentalnaia farmakokinetika albikara [Experimental pharmacokinetics of albicar]. Khimiko-farmatsevticheskii zhurnal - Pharmaceutical Chemistry Journal, 3, 13 -16 [in Russian]. 